REVIEW ARTICLE

\title{
Sand fly saliva: effects on host immune response and Leishmania transmission
}

\author{
Iva Rohoušová and Petr Volf
}

Department of Parasitology, Faculty of Science, Charles University, Viničná 7, 12844 Prague 2, Czech Republic

Key words: Phlebotomus, Lutzomyia, sand fly saliva, leishmaniasis, host immune response

\begin{abstract}
The feeding success of sand flies (Diptera: Phlebotominae) is linked to the vast array of pharmacological substances in their saliva, which interferes with the host haemostasis and immune response. Modification of feeding site plays also an important role in Leishmania transmission. In naive hosts, co-inoculation of saliva and Leishmania parasites increases the chance of successful transmission. Disease exacerbation seems to be associated with enhanced production of type 2 cytokines and selective inhibition of some macrophage functions including the production of $\mathrm{NO}$ and $\mathrm{H}_{2} \mathrm{O}_{2}$. On the other hand, hosts repeatedly exposed to sand fly bites develop anti-saliva immune response that results in a protection against Leishmania infection. This led to a new interesting approach to anti-Leishmania vaccine - using salivary components to block parasite transmission. The review is therefore focused on the interactions that run between immunomodulatory molecules in sand fly saliva and host immune response, with the impact on Leishmania infection development. Recent studies revealed that saliva-based vaccine for leishmaniasis might be effective and feasible, however, several questions still require to be solved. The knowledge based on experimental mouse model cannot be fully extrapolated to dogs or humans and due to differences in salivary antigens between sand fly species the protective effect is species-specific. On the other hand, the specificity of salivary antigens enables the use of anti-saliva antibodies for monitoring the exposure of hosts to sand fly bites and might be used as a marker of risks for Leishmania transmission in endemic areas.
\end{abstract}

Phlebotomine sand flies are Diptera of the family Psychodidae. Adults, both males and females, take sugar meals as a source of energy. Only females display haematophagy; they feed on vertebrate hosts, using the nutrients from blood meal for egg production. The feeding success is linked to the vast array of pharmacological substances in their saliva that are injected into their host while feeding.

The salivary glands have a sac-like structure consisting of a unicellular epithelium layer surrounding a large lumen serving as a container of saliva (Adler and Theodor 1926). The protein composition of the saliva depends on the physiological state of adults, their sex, and species of the sand fly. During the first days after emergence, females undergo physiological changes including the secretion of salivary proteins into the salivary gland lumen. The number of protein components gradually increases with the age of females, reaching the full electrophoretic pattern in 3-5 days after emergence. In females the protein concentration of saliva is higher and the protein content more complex than in males, which reflects different feeding strategies (Volf et al. 2000).

Sand flies are the vectors of Leishmania parasites, the causative agents of leishmaniasis. Within the vertebrate host, Leishmania parasites reside in phagocytic cells and induce a spectrum of diseases ranging from a single self-healing cutaneous lesion to lethal visceral form. It is estimated that this important group of diseases affects two million people per year (WHO 2005).

The saliva of the vector has an important role in parasite transmission. The haemostatic and immune modification of the feeding site affects Leishmania infection establishment. The immunomodulatory properties of sand fly saliva were studied almost exclusively in two species, Lutzomyia longipalpis and Phlebotomus papatasi. In the New World species L. longipalpis the well-known vasodilator is maxadilan since this molecule alone was described to modulate host immune responses to the similar degree as the whole saliva. The immunomodulatory molecule(s) in Phlebotomus saliva are currently less defined (Sacks and Kamhawi 2001).

\section{IMMUNOMODULATION OF NAIVE HOSTS}

Saliva of Lutzomyia and Phlebotomus species modulates the host immune response at different levels including both the innate and acquired immune response. Some of these effects on the host immune responses are common to both genera, some are specific.

\section{Lutzomyia longipalpis}

Saliva of L. longipalpis affects complement activation, T-cell proliferation, haematopoiesis, and various functions of antigen-presenting cells (e.g. monocytes, macrophages, and dendritic cells). The most studied 
host immune cells in terms of sand fly saliva immunomodulation are antigen-presenting cells. In these cells, L. longipalpis saliva/maxadilan modulates the secretion of various cytokines and alters the expression of costimulatory molecules. In human monocytes stimulated by lipopolysaccharide (LPS), L. longipalpis saliva decreases the secretion of TNF- $\alpha$ and IL-10 and increases the levels of IL-6, IL-8, and IL-12p40 (Costa et al. 2004). Analogous to whole saliva, maxadilan also inhibits TNF- $\alpha$ release and increases IL- 6 production in LPSstimulated human monocytes (Rogers and Titus 2003). In mice, these two cytokines are modulated in the same way both in vitro (Soares et al. 1998) and in vivo (Bozza et al. 1998).

Cytokines TNF- $\alpha$ and IL- 6 are mediators of acutephase inflammatory response. TNF- $\alpha$ is produced by monocytes and macrophages, as well as many other cells including $\mathrm{T}$ and $\mathrm{B}$ lymphocytes and fibroblasts. This cytokine increases the synthesis of factors favouring blood clotting, activates cytokine production, promotes MHC molecule expression, and has a cytotoxic effect on the infected cells (Klein and Hořejší 1997). Decreased production of TNF- $\alpha$ could also explain the inhibition of neutrophil migration observed in OVAimmunized mice treated with $L$. longipalpis saliva (Monteiro et al. 2005) since TNF- $\alpha$ enhances endothelial cell adhesiveness for inflammatory cells (Klein and Hořejší 1997).

Interleukin-6 is a multifunctional cytokine produced by several cell types and has a systemic effect on the immune system (primarily on B lymphocytes). It also stimulates haematopoiesis (Klein and Hořejší 1997). This is in agreement with the results of Guilpin et al. (2002), who found that maxadilan stimulates bone marrow haematopoiesis in mice. This results in an elevated number of erythroid and myeloid progenitors and circulating reticulocytes.

In addition to cytokine modulation, L. longipalpis saliva influences the expression of co-stimulatory molecules in antigen-presenting cells. In LPS-treated human monocytes, saliva decreases the expression of CD80 and enhances the expression of CD86 and HLA-DR. In macrophages, there is an increase in CD80 and HLADR expression but no alteration in CD86. The addition of saliva during dendritic cell generation leads to a decrease in CD80, CD86, HLA-DR, and CD1a expression. However, the intensity of the stimulatory and inhibitory effects varies depending on the individual (Costa et al. 2004). These changes in the expression of costimulatory molecules can alter the T-cell activation and response.

Another effect common to L. longipalpis saliva as well as maxadilan alone is a modulation of T-cell proliferation. Saliva is able to completely suppress the $T$ cell proliferative response to sheep red blood cells in vivo and to concanavalin A (ConA) in vitro (Titus 1998, Rohoušová et al. 2005a). Maxadilan inhibits splenocyte proliferation induced either by ConA or anti-T-cell receptor antibodies (Qureshi et al. 1996). The mechanism of the inhibitory effect is not well defined yet, however, the results suggest that saliva/maxadilan affects both APCs and T cells. The peptide can inhibit Tcell activation at the level of co-stimulatory signals or early IL-2 suppression (Qureshi et al. 1996, Costa et al. 2004, Rohoušová et al. 2005a).

Maxadilan also inhibits delayed-type hypersensitivity (DTH) in mice (Qureshi et al. 1996). Similarly, whole saliva injected intradermally in the mouse ear leads to a very modest infiltration of inflammatory cells, which subsides after 48 hours (Silva et al. 2005). However, the cell response is different in other experimental animals. Guinea pigs have marked basophilia and eosinophilia, which peak 3 days post-infestation (Brown and Rosalsky 1984). On the other hand, eosinophilia is not induced by L. longipalpis saliva in mongrel dogs (Paranhos et al. 1993).

Finally, complement activation is also affected; both L. longipalpis and L. migonei saliva inhibit classical pathway of complement activation, however, only $L$. longipalpis inhibits the alternative pathway of activation as well. The inhibitory molecule of the classical pathway present in the saliva of $L$. longipalpis is a heatstable protein of 10-30 kDa (Cavalcante et al. 2003). Many components of the complement system are serine proteases (Klein and Hořejší 1997), therefore the molecule with anti-complement activity could be a serine protease inhibitor recently found in the cDNA library of L. longipalpis saliva (Valenzuela et al. 2004).

\section{Phlebotomus papatasi}

In contrast to the extensive work performed with $L$. longipalpis, relatively little is known about the effects of saliva from the Old World sand flies. However, it is clear that some of these effects are common, some are specific. For example, similarly to L. longipalpis, saliva of $P$. papatasi has an inhibitory effect on lymphocyte proliferation. It suppresses early production of IL-2, IL4 , and IFN- $\gamma$ (Rohoušová et al. 2005a) and increases production of IL-6 (Rogers and Titus 2003). In addition, the propensity of saliva to induce positive macrophage chemotaxis is also common to several phlebotomine species, including both the genera Phlebotomus (Anjili et al. 1995, Zer et al. 2001) and Lutzomyia (Zer et al. 2001).

The interaction between $P$. papatasi saliva and macrophages also alters NO synthesis. Phlebotomus papatasi saliva down-regulates the expression of inducible NO synthase (iNOS) and subsequent production of NO in LPS- or IFN- $\gamma$-activated murine macrophages (Waitumbi and Warburg 1998, Katz et al. 2000). Katz et al. (2000) showed that salivary adenosine is the factor responsible for this down-regulation. This modulation is species-specific since no effect on NO synthesis was found in L. longipalpis saliva (Katz et al. 2000). 
Additionally, two important differences have been found between Lutzomyia and Phlebotomus saliva. Phlebotomus papatasi has no effect on TNF- $\alpha$ production by LPS-stimulated human monocytes (Rogers and Titus 2003). Besides, P. papatasi saliva up-regulates the expression of the Th2 cytokine IL-4 (Mbow et al. 1998). This cytokine induces the secretion of antibodies by $\mathrm{B}$ cells and acts also on T lymphocytes, monocytes, endothelial cells, and fibroblasts. Moreover, IL-4 selectively stimulates Th2 cell differentiation and suppresses Th1 cell development, thus preventing the development of inflammatory response (Klein and Hořejší 1997).

\section{IMMUNE RESPONSE OF THE HOST REPEATEDLY EXPOSED TO SAND FLY SALIVA}

Hosts repeatedly exposed to uninfected sand fly bites develop antibodies as well as cellular response. In experimental animals, antibodies to saliva of various sand flies were demonstrated by Belkaid et al. (1998), Ghosh and Mukhopadhyay (1998), Valenzuela et al. (2001), Volf and Rohoušová (2001), Rohoušová et al. (2005b) and Silva et al. (2005). Animals living in an endemic area of leishmaniasis such as dogs and pigs also develop anti-saliva antibodies (Paranhos-Silva et al. 2003, Milleron et al. 2004a). Most of the IgG produc-tion is represented by the IgG1 subclass, whereas $\operatorname{IgG} 2 \mathrm{a}$ and IgG2b remain near background (Silva et al. 2005). So far as we are aware, there are no data about anti-saliva antibodies of other classes such as IgE or IgM.

Recently, the production of antibodies against the sand fly saliva has been demonstrated in humans as well (Barral et al. 2000, Gomes et al. 2002, Rohoušová et al. 2005b). People living in endemic areas of leishmaniasis in Brazil and Turkey showed high levels of anti-saliva IgG, specific to the local sand fly species. The antibodies recognise most of the salivary proteins, however the frequency and intensity of recognition varied among individuals (Gomes et al. 2002, Rohoušová et al. $2005 \mathrm{~b}$ ). A protein band corresponding to the molecular weight of maxadilan has been recognized by only two serum samples out of 13 . This suggests that maxadilan may not induce a strong antibody response in humans (Gomes et al. 2002). The main antigen in L. longipalpis saliva is a protein of $45 \mathrm{kDa}$ (Gomes et al. 2002); in $P$. papatasi human sera strongly reacted with a $30-\mathrm{kDa}$ protein band (Rohoušová et al. 2005b). These two proteins could be used for monitoring the exposure of humans to sand fly bites as a risk factor for Leishmania transmission.

Cell-mediated immunity is also affected by preexposure to sand fly saliva. In mice, L. longipalpis saliva induces an intense and diffuse inflammatory cell infiltration characterized by neutrophils, eosinophils, and macrophages; the reaction persists for up to 48 hours (Silva et al. 2005). In guinea pigs, repeated feeding by the same sand fly species resulted in a weak basophilia and a strong eosinophilia (Brown and Rosalsky 1984).

For $P$. papatasi, it has been known for decades that the bites can induce DTH response in humans, a condition known as harara (Theodor 1935). In sensitized mice, $P$. papatasi saliva causes cell infiltration in the ear dermis, which peaks between 18 and 48 hours. This remains higher than the control for a period of 5 days. The infiltrate is composed mainly of $\mathrm{CD}^{+}$lymphocytes, eosinophils, monocytes/macrophages, neutrophils, and dendritic cells (Belkaid et al. 2000). In agreement with these data, saliva of Phlebotomus species has been found to be chemotactic to mouse monocytes (Anjili et al. 1995, Zer et al. 2001).

Mice develop this strong DTH response even after a double exposure to the equivalent of 0.1 salivary gland of $P$. papatasi inoculated intradermally in the ear. The same cellular infiltrate is mobilised in the skin after the bite of sand flies (Belkaid et al. 2000). It is interesting that only a small number of salivary molecules are responsible for the induction of the DTH response and that the response to these antigens is restricted to the genetic background of the host (Belkaid et al. 2000, Valenzuela et al. 2001, Oliveira et al. 2006).

Immunisation by recombinant maxadilan elicits both, a humoral and a cellular response. Serum of vaccinated mice contains high titres of anti-maxadilan antibodies and lymph node cells are stimulated to produce IFN- $\gamma$ and NO (Morris et al. 2001). Although maxadilan variants have equivalent vasodilatory potency (Lanzaro et al. 1999), the polymorphism in amino acid sequence modifies the antigenicity of this molecule (Milleron et al. 2004a). The antibodies elicited by different maxadilans are variant-specific with little cross-reactivity. There is an antigenic variability between $L$. longipalpis populations as well as within a single population (Milleron et al. 2004a).

The antibodies against saliva/maxadilan can block some of the saliva functions and subsequently have a negative impact on feeding success. Anti-L. longipalpis saliva antibodies have been shown to partially inactivate the complement inhibitor (Cavalcante et al. 2003) and completely abrogate the effect of $L$. longipalpis saliva on cytokine production by LPS-stimulated human monocytes (Costa et al. 2004). Moreover, antimaxadilan antibodies decrease vasodilatory function of maxadilan in sensitized mice, which subsequently reduces blood meal acquisition and egg production of $L$. longipalpis (Milleron et al. 2004b). These effects are specific since anti-maxadilan antibodies have no influence on blood feeding of $P$. papatasi (Milleron et al. 2004b). However, observations in various sand fly colonies revealed that antibodies in mice repeatedly bitten by sand flies affect neither feeding success nor fecundity and longevity of sand flies (Volf et al., unpublished). 


\section{COMPONENTS ENHANCING LEISHMANIA TRANSMISSION}

Sand fly females with mature infections inoculate about 10 to 1,000 Leishmania parasites into the skin (Warburg and Schlein 1986, Rogers et al. 2004). However, experimental inoculation of susceptible mice with comparably low numbers of parasites usually does not cause disease but rather promotes the immunity (Menon and Bretscher 1996). Therefore, to induce Leishmania infection in experimental mice, investigators commonly inject thousands or millions of parasites.

The sand fly efficiency as a vector is influenced by the ability to inject "exacerbating factors" along with Leishmania parasites. Such factors could assist the establishment of the parasites in the mammalian host and could be both parasite- and sand fly-derived. Thus, vectorial capacity of a given sand fly species should be a reflection of its ability to generate infective forms of Leishmania and subsequently to enhance transmission of the parasite. The infective inoculum contains two important components: vector saliva and promastigote secretory gel (PSG) (Titus and Ribeiro 1988, Rogers et al. 2004).

The role of PSG in the establishment of Leishmania infection was recently demonstrated by Rogers et al. (2004). PSG is a gel-like material containing the majority of the total metacyclic promastigotes in the sand fly (Stierhof et al. 1999, Rogers et al. 2002b). The main component of PSG is filamentous proteophosphoglycan. Additionally, there are other parasite-secreted glycans together with a limited number of minor protein components. PSG from infected $L$. longipalpis increases both pathogenicity and survival of Leishmania mexicana in mice. In this parasite-vector model PSG produced larger exacerbating effect than saliva (Rogers et al. 2004). However, saliva is protective also when coinjected with Leishmania parasites and PSG by the bite of infected sand fly (Kamhawi et al. 2000).

In contrast to PSG, more is known about the role of sand fly saliva in the development of Leishmania infection. Interactions that run between immunomodulatory molecules in sand fly saliva and host immune response have also an impact on Leishmania infection development. The following two sections summarize the dual role of sand fly saliva in leishmaniasis context.

\section{ENHANCING EFFECT OF SAND FLY SALIVA}

In naive mice the effects of sand fly saliva make the site of inoculation more favourable for the initial step of Leishmania infection. The salivary pharmacological activities released at the same site with the parasites increase the chance of successful transmission since Leishmania co-injected with saliva become much more virulent. This observation has been found true for different sand fly-Leishmania combinations, including the unnatural ones. It is interesting to note that the enhanc- ing effect on the course of Leishmania major infection is unique to the sand fly, since saliva from Aedes aegypti, Rhodnius prolixus, or Ixodes scapularis (syn. I. dammini) has no effect (Titus and Ribeiro 1988). Data published by various authors on different Leishmaniasand fly combination are summarized in Table 1.

\section{L. longipalpis - Le. major}

In some murine models of Le. major infection, the presence of L. longipalpis saliva in the infective inoculum determined whether or not parasites caused the lesion (Titus and Ribeiro 1988, Theodos et al. 1991). The enhancing effect of saliva could be measured both by lesion size and by higher parasite burden, affecting the long-term pathology of the disease (Titus and Ribeiro 1988). Sand fly saliva is very potent in its ability to enhance infection; salivary gland material from $L$. longipalpis is able to enhance the infectivity of $L e$. major even when injected as much as 4 days prior to the injection of the parasite (Theodos and Titus 1993). Similar effect was also detected when L. longipalpis fed on mice prior to injecting Le. major at the same site (Theodos et al. 1991). Enhancement of parasite infectivity was demonstrated in various inbred strains of mice with different levels of resistance to Leishmania infection, although the extent and kinetics of the enhancement varied from strain to strain (Theodos et al. 1991).

The effect of $L$. longipalpis saliva on Le. major infection is dose-dependent. The amount as low as 1/250 of a gland has an observable effect on the course of the infection (Theodos et al. 1991). The exacerbation increases with increasing doses of saliva, up to a maximum of 0.5 and 1.0 gland equivalents; a higher dose (two glands equivalent) has a reduced effect (Morris et al. 2001).

The enhancing effect of L. longipalpis saliva could be mediated by the functional alteration of antigenpresenting cells. L. longipalpis saliva affects the ability of infected macrophages to present Leishmania antigens to T cells (Theodos and Titus 1993). Saliva inhibits the antigen presentation process via a direct effect on macrophages, since macrophages preincubated with salivary gland lysate fail to stimulate Leishmaniaspecific $\mathrm{T}$ cell proliferation, regardless of the mouse strain used to generate the $\mathrm{T}$ cells (Theodos and Titus 1993). This is mediated, at least in part, by the modulatory effect of L. longipalpis saliva on cytokine secretion and/or expression of costimulatory molecules (Costa et al. 2004, Rohoušová et al. 2005a). In addition, L. longipalpis saliva also inhibits $\mathrm{H}_{2} \mathrm{O}_{2}$ production by IFN- $\gamma$ activated macrophages (Titus and Ribeiro 1990).

The major molecule responsible for exacerbation activity of L. longipalpis saliva is maxadilan. Morris et al. (2001) demonstrated that maxadilan exacerbates infection with Le. major to the same degree as the whole saliva. Indeed, maxadilan has several effects on macrophages that would explain its ability to exacerbate Leishmania infection and to prolong the survival of the 
Table 1. Enhancing effect of sand fly saliva on the course of Leishmania infection in mice and other hosts; summary of the data published by various authors.

\begin{tabular}{|c|c|c|c|}
\hline Sand fly / Leishmania & Infective inoculum & Host & Reference \\
\hline \multicolumn{4}{|l|}{ Lutzomyia longipalpis } \\
\hline \multirow[t]{12}{*}{ Le. major } & $10^{5}$ promastigotes +0.5 gland & $\mathrm{BALB} / \mathrm{c}, \mathrm{CBA} / \mathrm{T} 6$ & Titus and Ribeiro 1988 \\
\hline & $10^{4}, 10^{3}, 10^{2}, 10^{1}$ promastigotes +0.5 gland & $\mathrm{CBA} / \mathrm{Ca}$ & Titus and Ribeiro 1988 \\
\hline & $10^{5}$ promastigotes +0.5 gland & $\begin{array}{l}\mathrm{BALB} / \mathrm{c}, \mathrm{CBA} / \mathrm{Ca} \text {, } \\
\mathrm{C} 57 \mathrm{BL} / 6, \\
\mathrm{C} 3 \mathrm{H} / \mathrm{HeN}, \mathrm{DBA} / 2\end{array}$ & Theodos et al. 1991 \\
\hline & $10^{5}$ promastigotes $+1,0.5,0.1,0.02$, or 0.04 gland & $\mathrm{CBA} / \mathrm{Ca}$ & Theodos et al. 1991 \\
\hline & $10^{5}$ promastigotes one hour after blood feeding & $\mathrm{C} 57 \mathrm{BL} / 6$ & Theodos et al. 1991 \\
\hline & $10^{5}$ promastigotes +0.5 gland & $\mathrm{CBA} / \mathrm{T} 6 \mathrm{~J}$ & Theodos and Titus 1993 \\
\hline & 0.5 gland 2 and 4 days prior to $10^{5}$ promastigotes & CBA/T6J & Theodos and Titus 1993 \\
\hline & $10^{5}$ promastigotes +0.5 gland & CBA/T6 & Warburg et al. 1994 \\
\hline & $10^{5}$ promastigotes $+0.1,0.5,1$, or 2 glands & $\mathrm{CBA} / \mathrm{CaH}-\mathrm{T} 6 \mathrm{~J}$ & Morris et al. 2001 \\
\hline & $10^{5}$ promastigotes $+1,3,10 \mathrm{ng}$ of synthetic MAX & $\mathrm{CBA} / \mathrm{CaH}-\mathrm{T} 6 \mathrm{~J}$ & Morris et al. 2001 \\
\hline & $10^{5}$ promastigotes +1 gland & CBA & Castro-Sousa et al. $2001^{1}$ \\
\hline & $10^{5}$ promastigotes $+1,5,50,100 \mathrm{ng}$ of maxadilan & CBA & Castro-Sousa et al. $2001^{1}$ \\
\hline \multirow{6}{*}{ Le. chagasi } & $10^{4}, 10^{5}, 10^{6}, 10^{7}$ promastigotes +2 glands & golden hamster & Melo et al. 2001 \\
\hline & $2 \times 10^{5}$ promastigotes +2 glands & mongrel dog & Paranhos et al. $1993^{1}$ \\
\hline & $10^{3}$ promastigotes +0.5 gland & $\mathrm{BALB} / \mathrm{c}$ & Warburg et al. 1994 \\
\hline & $10^{4}$ promastigotes +2 glands & hamster & Warburg et al. 1994 \\
\hline & $13.5 \times 10^{7}$ amastigotes +2 glands & $\begin{array}{l}\text { Didelphis } \\
\quad \text { marsupialis }\end{array}$ & Travi et al. $1998^{1,2}$ \\
\hline & $1.04 \times 10^{4}$ promastigotes +0.5 gland & Beagle dog & $\begin{array}{l}\text { Paranhos-Silva et al. } \\
2003^{1}\end{array}$ \\
\hline \multirow[t]{4}{*}{ Le. braziliensis } & $10^{5}$ promastigotes $+1,5,50,100 \mathrm{ng}$ of maxadilan & $\mathrm{BALB} / \mathrm{c}$ & Castro-Sousa et al. $2001^{1}$ \\
\hline & $10^{6}$ parasites +0.5 gland & $\mathrm{BALB} / \mathrm{c}$ & Samuelson et al. 1991 \\
\hline & $10^{3}-10^{7}$ promastigotes +0.5 gland & $\begin{array}{l}\mathrm{BALB} / \mathrm{c}, \mathrm{C} 3 \mathrm{H} / \mathrm{HeJ}, \\
\mathrm{C} 57 \mathrm{BL} / 6, \mathrm{DBA} / 2 \text {, } \\
\mathrm{CBA} / \mathrm{Ca}\end{array}$ & Lima and Titus $1996^{3}$ \\
\hline & $10^{7}$ promastigotes +0.5 gland & $\mathrm{BALB} / \mathrm{c}$ & Donnelly et al. 1998 \\
\hline \multirow[t]{3}{*}{ Le. mexicana } & N.D. & $\mathrm{BALB} / \mathrm{c}, \mathrm{C} 3 \mathrm{H}$ & Samuelson et al. 1991 \\
\hline & by bite & $\mathrm{BALB} / \mathrm{c}, \mathrm{CBA} / \mathrm{Ca}$ & Rogers et al. 2004 \\
\hline & $10^{3}$ promastigotes $+1 \mu \mathrm{g}$ of saliva & $\mathrm{BALB} / \mathrm{c}, \mathrm{CBA} / \mathrm{Ca}$ & Rogers et al. $2004^{1}$ \\
\hline \multirow{4}{*}{ Le. amazonensis } & $10^{6}$ promastigotes +0.5 gland & $\mathrm{BALB} / \mathrm{c}, \mathrm{CBA} / \mathrm{Ca}$ & Theodos et al. 1991 \\
\hline & $10^{8}$ promastigotes + N.D. amount of gland(s) & Macaca mulatta & Amaral et al. $1996^{1,4}$ \\
\hline & $10^{5}$ promastigotes +0.5 gland & $\mathrm{BALB} / \mathrm{c}$ & Norsworthy et al. 2004 \\
\hline & $10^{6}$ promastigotes +1 gland & $\mathrm{BALB} / \mathrm{c}$ & Thiakaki et al. 2005 \\
\hline \multicolumn{4}{|l|}{ Lutzomyia youngi } \\
\hline Le. braziliensis & homogenized human biopsy tissue +1 gland & hamster & Rojas and Scorza 1995 \\
\hline Lutzomyia whitmani & & & \\
\hline \multicolumn{4}{|l|}{ Phlebotomus papatasi } \\
\hline \multirow[t]{4}{*}{ Le. major } & $10^{5}$ promastigotes +0.5 gland & $\begin{array}{l}\text { C } 57 \mathrm{BL} / 6, \mathrm{BALB} / \mathrm{c}, \\
\mathrm{C} 3 \mathrm{H}\end{array}$ & Theodos et al. 1991 \\
\hline & $10^{5}$ promastigotes +0.5 gland & CBA & Mbow et al. 1998 \\
\hline & $10^{3}$ promastigotes +0.1 gland & $\mathrm{BALB} / \mathrm{c}, \mathrm{C} 57 \mathrm{BL} / 6$ & Belkaid et al. 1998 \\
\hline & 500 promastigotes +1 gland & $\mathrm{C} 57 \mathrm{BL} / 6$ & Valenzuela et al. 2001 \\
\hline \multicolumn{4}{|c|}{ Phlebotomus perniciosus } \\
\hline Le. infantum & $5-8 \times 10^{3}$ promastigotes +0.5 gland & Beagle dog, hamster & $\begin{array}{l}\text { Killick-Kendrick et al. } \\
1994^{1,5}\end{array}$ \\
\hline
\end{tabular}

\footnotetext{
${ }^{1}$ the enhancing effect was not pronounced; ${ }^{2}$ four animals were infected, each in a different way (intradermally or intracardially) with or without salivary glands; ${ }^{3}$ saliva did not affect Le. braziliensis infection in any of the other mouse strains than BALB/c; ${ }^{4}$ the rhesus monkey was subsequently challenged with this inoculum after recovery from the primary infection with promastigotes alone; ${ }^{5}$ inoculum of parasites with and without salivary gland lysate (SGL) received the same animal; N.D. - - not defined; MAX - maxadilan
} 
parasite in the host. It inhibits production of IFN- $\gamma$ and IL-12p40 subunit and induces IL-6 production by human monocytes/macrophages stimulated with Le. major (Rogers and Titus 2003). This may alter the host immune response, favouring the development of a Th2 immune response that supports disease progress (reviewed by Rogers et al. 2002a). In addition, maxadilan alone has also a biphasic dose-response effect on $L e$. major lesion development (Morris et al. 2001).

It is known that species of the L. longipalpis complex differ in their amounts of salivary maxadilan (Warburg et al. 1994). If maxadilan is the principal molecule of exacerbating effect, the sibling species will probably differ in their vectorial capacities. Indeed, Costa Rican L. longipalpis, that have very little maxadilan, strongly enhance cutaneous proliferation of Leishmania infection. Conversely, flies from Brazil with more maxadilan facilitate early visceralization of the infection, thus exacerbating cutaneous infection to a lesser degree (Warburg et al. 1994).

\section{L. longipalpis - Le. braziliensis}

The enhancing effects of $L$. longipalpis saliva allowed development of a mouse model for Le. braziliensis infection. When injected with sand fly saliva, Le. braziliensis infection is significantly enhanced as measured by lesion size, parasite burden, and the outcome of infection. In saliva-treated mice, the lesions progress to extensive accumulation of parasitized macrophages persisting for the lifetime of the mice (Samuelson et al. 1991, Lima and Titus 1996, Donnelly et al. 1998).

The enhancing effect on Le. braziliensis infection is dependent on the dose of parasites inoculated. Saliva does not significantly enhance infection when a dose of $10^{4}$ or fewer was used (Lima and Titus 1996). This is in contrast to results with Le. major infection when saliva markedly enhanced infection even with the low dose of 10 parasites (Titus and Ribeiro 1988). The outcome of Le. braziliensis infection is also affected by the host genetic background, since $L$. longipalpis saliva enhanced infection only in BALB/c mice and not in any other mouse strain tested (Lima and Titus 1996).

The mechanism by which L. longipalpis saliva enhances Le. braziliensis infection seems to be IL-4 dependent. This cytokine is able to block the ability of IFN- $\gamma$ to activate macrophages to kill intracellular Leishmania parasites (Lehn et al. 1989). Lymph node cells from mice infected with or without saliva and restimulated ex vivo with Le. braziliensis do not differ in the secretion of IL-2, IL-10, IFN- $\gamma$ or TNF- $\alpha$ cytokines. However, the cells from saliva-treated mice up-regulate IL-4 production. Treatment with a neutralizing anti-IL-4 antibody abrogates the exacerbative effects of $L$. longipalpis saliva on Le. braziliensis infection (Lima and Titus 1996). It is possible that IL-4 production is not directly affected, but rather that saliva regulates IL-4 production through the modulation of other cytokine production or receptor expression.
There is a difference in the outcome of Le. braziliensis infection when the parasites are injected with $L$. longipalpis saliva or with saliva of its natural vector, $L$. whitmani. When injected with L. whitmani saliva, Le. braziliensis lesions increase only in size but heal similarly to controls (Bezerra and Teixeira 2001).

\section{L. longipalpis - Le. amazonensis}

Lutzomyia longipalpis saliva also enhances the infectivity of another New World Leishmania - Le. amazonensis (Theodos et al. 1991). This effect is obvious in both BALB/c and CBA mice (Theodos et al. 1991). In saliva-treated mice, the lesions are larger and contain more parasites, however, there is no change in the infection rate or intracellular growth of Le. amazonensis in murine macrophages (Theodos et al. 1991, Norsworthy et al. 2004). Lymph node cells from saliva-treated mice produce more IL- 4 and IL-10, but there are no differences in the production of other cytokines such as IL-2, IL-6, TNF- $\alpha$, and IFN- $\gamma$ (Norsworthy et al. 2004). In contrast to Le. braziliensis, the promotion of Le. amazonensis infectivity is mediated by stimulating IL-10 production rather than IL-4 (Norsworthy et al. 2004). In addition, L. longipalpis saliva suppresses parasiteinduced NO production in macrophages (Norsworthy et al. 2004).

\section{L. longipalpis - Le. chagasi}

All the above-mentioned results, however impressive, do not mimic natural conditions, since L. longipalpis is not a vector of Le. major, Le. braziliensis nor Le. amazonensis, but of Le. chagasi (reviewed by KillickKendrick 1990, Sádlová 1999). The coinjection of Le. chagasi with its vector saliva also enhances parasite infectivity in mice (Warburg et al. 1994). On the other hand, L. longipalpis saliva does not enhance experimental infection of Le. chagasi in dogs (Paranhos et al. 1993, Paranhos-Silva et al. 2003); the addition of $L$. longipalpis saliva does not lead to early detection of amastigotes in the spleen or to an increase in parasite burden in internal organs (Paranhos-Silva et al. 2003).

\section{P. papatasi-Le. major}

Phlebotomus papatasi is the natural vector of Le. major (reviewed by Killick-Kendrick 1990). Despite a different composition of saliva, it enhances Le. major infection in a similar manner to L. longipalpis; lesions appear earlier, are more destructive, and contain greater numbers of parasites (Belkaid et al. 1998, Mbow et al. 1998). Preliminary studies indicate that a mixture of adenosine and AMP is as powerful enhancer of Leishmania infection as is the whole saliva of $P$. papatasi (Valenzuela et al. 2001).

Based on studies with various mouse strains, the disease exacerbation seems to be associated with the enhanced production of type 2 cytokines, primarily IL-4 (Belkaid et al. 1998, Mbow et al. 1998), since the IL-4 deficiency eliminates any effect of $P$. papatasi saliva on disease exacerbation (Belkaid et al. 1998). However, 
this early IL-4 response is observed only after the intradermal inoculation but is not elicited by bites of infected sand flies (Kamhawi et al. 2000). After the infective bite, epidermal cells show a strong up-regulation of IL-2 and IL-3 cytokines (Kamhawi et al. 2000).

Similar discrepancies have been shown for IFN- $\gamma$ production. When Le. major is coinjected with $P$. papatasi saliva, this cytokine is down-regulated in epidermal cells (Belkaid et al. 1998) as well as in the lymph nodes draining the lesion (Mbow et al. 1998). Phlebotomus papatasi saliva also inhibits IFN- $\gamma$ production by human monocytes stimulated with Le. major (Rogers and Titus 2003). On the other hand, after the infective bite, the production of IFN- $\gamma$ is slightly enhanced (Kamhawi et al. 2000).

A critical function of IFN- $\gamma$ is its ability to activate microbicidal activity in macrophages, including NO production (Klein and Hořejší 1997). Although $P$. papatasi saliva does not alter uptake of Le. major by macrophages (Hall and Titus 1995), it may promote the infection by inhibiting the subsequent destruction of the parasite. Indeed, $P$. papatasi saliva inhibits expression of the iNOS gene, and subsequent production of $\mathrm{NO}$ in infected macrophages both in vitro (Hall and Titus 1995, Waitumbi and Warburg 1998) and in vivo (Mbow et al. 1998). The down-regulation of iNOS expression and the resultant reduction in NO production caused by $P$. papatasi saliva may promote proliferation of amastigotes within infected macrophages. It has been demonstrated that adenosine is probably the factor in $P$. $p a-$ patasi saliva that interferes with the ability of activated macrophages to kill parasites (Katz et al. 2000). This is in agreement with the observed enhancing effect of pure mixture of adenosine and AMP (Valenzuela et al. 2001). The inhibition of iNOS could result at least in part from the down-regulation of IFN- $\gamma$ (Belkaid et al. 1998, Mbow et al. 1998, Rogers and Titus 2003); therefore the question is whether a bite of infected $P$. papatasi also results in an inhibition of NO production.

\section{ProteCtive EFFECT OF ANTI-SALIVA IMMUNE RESPONSE}

Several investigators have shown that the immunity elicited by sand fly saliva allows the host to develop protection against Leishmania infection (Table 2). It appears that pre-exposure of mice to salivary gland proteins or saliva decreases the severity of a subsequent infection with Leishmania (Belkaid et al. 1998, Kamhawi et al. 2000, Morris et al. 2001, Valenzuela et al. 2001). This fact leads to the interesting possibility that vaccinating the host against the components of vector saliva will inhibit Leishmania transmission. Indeed, mice pre-exposed to sand fly saliva are at much reduced risk of severe leishmaniasis (Belkaid et al. 1998, Kamhawi et al. 2000), suggesting that alternative approaches, such as vaccinating against the vector, may offer important new methods for controlling leishmaniasis.

To date, there are only two published studies aimed at the use of sand fly salivary molecules as a transmission blocking vaccine against leishmaniasis. Morris et al. (2001) reported that mice vaccinated with recombinant maxadilan, the vasodilator of $L$. longipalpis saliva, are protected against infection with Le. major plus whole saliva of this sand fly species. In the second study, vaccination with one protein from $P$. papatasi saliva - PpSP15 - also protects mice against Le. major infection (Valenzuela et al. 2001). Results of both studies suggest that a saliva-based vaccine for leishmaniasis might be effective and feasible. However, this is not an easy task, and several questions still require to be solved. Some of them are mentioned below.

First of all, the explanation of this anti-Leishmania effect is not straightforward. Saliva is able to induce both antibody response and cell immune response and the discussion is still ongoing which one can explain the protective effect.

Anti-saliva antibodies counteract with the effect of saliva on host immune cells (Costa et al. 2004) as well as on disease exacerbation (Belkaid et al. 1998). Specific antibody levels correlate well with the simultaneous appearance of the protective immunity against Leishmania infection (Gomes et al. 2002). However, the protective role of antibodies is still questionable. Despite frequent bites of uninfected sand flies and high specific antibody levels in humans (Rohoušová et al. 2005b) the disease incidence in endemic areas is still high. The argument against the role of antibody in the protection comes also from the observation that vaccination with PpSP15 was successful even in B celldeficient mice that lack antibody production (Valenzuela et al. 2001).

The data from the Old World suggest that these antibodies reflect more likely the exposure to sand fly bites (Louzir et al. 2005, Rohoušová et al. 2005b) and could be used for monitoring the exposure of humans, domestic animals, and other hosts to sand flies. In endemic areas, the host response to sand fly bites might serve as a marker of risk for Leishmania transmission (Rohoušová et al. 2005b).

To bring more light into this subject, the components of sand fly saliva have been recently tested for their ability to induce a DTH or an antibody response together with to protect host against Leishmania challenge. The salivary proteins differ in their capacity to induce host immune response; they can induce antibody response or DTH or a combination of both (Oliveira et al. 2006). It has been found that cDNA vaccine based on proteins that induce a strong humoral response does not protect hamsters from Le. chagasi infection. On the contrary, immunisation with proteins that induce a DTH response (e.g. LLsp11 cDNA construct) lead to protection for up to 6 month (Brodskyn et al. 2005). Based on 
Table 2. Sand fly saliva protective effect on the course of Leishmania infection in mice; summary of the data published by various authors.

\begin{tabular}{|c|c|c|c|}
\hline Sand fly / vaccine & Infective inoculum & Host & Reference \\
\hline \multicolumn{4}{|l|}{ Lutzomyia longipalpis } \\
\hline synthetic maxadilan & $10^{5}$ Le. major +0.5 gland & $\mathrm{CBA}$ & Morris et al. 2001 \\
\hline salivary gland lysate & $10^{6}$ Le. amazonensis +1 gland & $\mathrm{BALB} / \mathrm{c}$ & Thiakaki et al. $2005^{*}$ \\
\hline \multicolumn{4}{|l|}{ Phlebotomus papatasi } \\
\hline salivary gland sonicate & $10^{3}$ Le. major +0.1 gland & $\mathrm{BALB} / \mathrm{c}, \mathrm{C} 57 \mathrm{BL} / 6$ & Belkaid et al. 1998 \\
\hline by bite & by bite & $\mathrm{BALB} / \mathrm{c}, \mathrm{C} 57 \mathrm{BL} / 6$ & Kamhawi et al. 2000 \\
\hline SGH gel fraction below $20 \mathrm{kDa}$ & 500 Le. major +1 gland & $\mathrm{C} 57 \mathrm{BL} / 6$ & Valenzuela et al. 2001 \\
\hline SP15 band & 500 Le. major +1 gland & $\mathrm{C} 57 \mathrm{BL} / 6$ & Valenzuela et al. 2001 \\
\hline SP15 based cDNA vaccine & 500 Le. major +1 gland & $\mathrm{C} 57 \mathrm{BL} / 6 \mathrm{wt}$ and $\mathrm{B}^{-/-}$ & Valenzuela et al. 2001 \\
\hline
\end{tabular}

$\mathrm{SGH}$, salivary gland sonicate; SP15, salivary protein of $15 \mathrm{kDa}$; ${ }^{*}$ the protective effect was not observed when mice were immunized with saliva of $P$. papatasi or $P$. sergenti and then challenged with Leishmania in the presence of $L$. longipalpis saliva.

these results, the protective effect of sand fly saliva is more likely associated with cell-mediated immunity.

Another problem to be solved is a complex epidemiology situation in leishmaniasis. Various Leishmania species are transmitted in nature by different sand fly vectors (reviewed by Ashford 2000). To date, information about salivary components and their immunomodulatory effects are referring mainly to $P$. papatasi and $L$. longipalpis. Recently, the most abundant secreted proteins have been identified also from the salivary glands of $P$. ariasi, $P$. argentipes and $P$. perniciosus (Anderson et al. 2006, Oliveira et al. 2006). Sand fly species differ in protein composition (Volf et al. 2000, Anderson et al. 2006) as well as in pharmacological activities of saliva (Warburg et al. 1994, Černá et al. 2002, Cavalcante et al. 2003); this may influence the protective effect on the progress of Leishmania infection. We have shown that antigens in sand fly saliva are species-specific (Volf and Rohoušová 2001, Rohoušová et al. 2005b) and, what is even more important, the protective effect is specific as well (Thiakaki et al. 2005). This specificity should be born in mind when designing vector-based vaccine.

The efficiency of vector salivary proteins as vaccine candidates could also be influenced by the intraspecific variability of these proteins. Some proteins, e.g. maxadilan, possess a high variability as measured by amino acid and/or nucleotide sequences (Warburg et al. 1994, Lanzaro et al. 1999, Milleron et al. 2004a). The observation that maxadilan displays antigenic diversity (Milleron et al. 2004a) could make the application of this protein in a vaccine harder. Designing a successful vaccine with maxadilan may require to combine all its different immunogenic forms. From this point of view the protein PpSP15 from $P$. papatasi saliva would be a better candidate. Based on the small number of PpSP15 variants (Elnaiem et al. 2005), this protein may have little antigenic variation and may therefore induce a uniform immune response by the host. It should be also noted, that immunosuppressive components of Phlebotomus saliva are adenosine and AMP. It will be difficult, if not impossible, to produce a vaccine against these components. However, immunisation against peptidic components of saliva may produce inflammatory reactions in the skin site that may counteract the immunosuppressive effects of Phlebotomus saliva, as has been shown for PpSP15 in a mouse model (Valenzuela et al. 2001).

Finally, it is important to mention that most of our knowledge is based on an experimental mouse model of leishmaniasis and cannot necessarily be extrapolated to other animals or humans. Valenzuela et al. (2005) have recently shown that salivary proteins induce different types of immune response (DTH and/or antibody response) even in different experimental animals, such as mice versus hamsters. Moreover, the human immune response to sand fly saliva is individual (Costa et al. 2004, Rohoušová et al. 2005b). A useful tool for an efficient screening of immunomodulatory proteins in sand fly saliva has been recently presented by Oliveira et al. (2006). The reverse antigen screening (RAS) approach includes a method of characterisation the host immune response after sand fly saliva immunisation by the injection of DNA plasmids coding for salivary transcripts. This method would significantly help to identify the best vaccine candidate directed to a certain host species. It can be used not only in mouse model but also in animals targeted by the vaccine, such as dogs and primates.

In conclusion, the recent work has revealed that the concept of using non-parasite components to induce a protective immunity against parasite transmission is an exciting approach toward vaccination against vectorborne pathogens including Leishmania. Ideally, longlasting immunity can be achieved through a combination of vaccine components directed against both vector and pathogen targets.

Acknowledgements. We would like to thank Dr. Jan Kolár̆ for critically reading the manuscript and Prof. P. Billingsley for valuable comments and suggestions. This work was supported by the Ministry of Education, Youth and Sports of the Czech Republic (VZ 0021620828 and LC 06009) and by the Czech Science Foundation (206/06/P015 and 206/06/0967). 


\section{REFERENCES}

ADLER S., THEODOR O. 1926: The mouthparts, alimentary tract and salivary apparatus of the female in Phlebotomus papatasi. Ann. Trop. Med. Parasitol. 20: 109-128.

AMARAL V.F., RANSATTO V.A.O., CONCEICAO-SILVA F., MOLINARO E., FERREIRA V., COUTINHO S.G., MCMAHON-PRATT D., GRIMALDI G. 1996: Leishmania amazonensis: the Asian rhesus macaques (Macaca mulatta) as an experimental model for study of cutaneous leishmaniasis. Exp. Parasitol. 82: 34-44.

ANDERSON J.M., OLIVEIRA F., KAMHAWI S., MANS B.J., REYNOSO D., SEITZ A.E., LAWYER P., GARFIELD M., PHAM M.V., VALENZUELA J.G. 2006: Comparative salivary gland transcriptomics of sandfly vectors of visceral leishmaniasis. BMC Genomics 7: $52-75$.

ANJILI C.O., MBATI P.A., MWANGI R.W., GITHURE J.I., OLOBO J.O., ROBERT L.L., KOECH D.K. 1995: The chemotactic effect of Phlebotomus duboscqi (Diptera: Psychodidae) salivary gland lysates to murine monocytes. Acta Trop. 60: 97-100.

ASHFORD R.W. 2000: The leishmaniasis as emerging and reemerging zoonoses. Int. J. Parasitol. 30: 1269-1281.

BARRAL A., HONDA E., CALDAS A., COSTA J., VINHAS V., ROWTON E.D., VALENZUELA J.G., CHARLAB R., BARRAL-NETTO M., RIBEIRO J.M.C. 2000: Human immune response to sand fly salivary gland antigens: a useful epidemiological marker? Am. J. Trop. Med. Hyg. 62: 740-745.

BELKAID Y., KAMHAWI S., MODI G., VALENZUELA J., NOBEN-TRAUTH N., ROWTON E., RIBEIRO J., SACKS D.L. 1998: Development of a natural model of cutaneous leishmaniasis: powerful effects of vector saliva and saliva preexposure on the long-term outcome of Leishmania major infection in the mouse ear dermis. J. Exp. Med. 188: 1941-1953.

BELKAID Y., VALENZUELA J.G., KAMHAWI S., ROWTON E., SACKS D.L., RIBEIRO J.M.C. 2000: Delayed-type hypersensitivity to Phlebotomus papatasi sand fly bite: An adaptive response induced by the fly? Proc. Natl. Acad. Sci. USA 97: 6704-6709.

BEZERRA H.S.D., TEIXEIRA M.J. 2001: Effect of Lutzomyia whitmani (Diptera: Psychodidae) salivary gland lysates on Leishmania (Viannia) braziliensis infection in BALB/c mice. Mem. Inst. Oswaldo Cruz 96: 349-351.

BOZZA M., SOARES M.B.P., BOZZA P.T., SATOSKAR A.R., DIACOVO T.G., BROMBACHER F., TITUS R.G., SHOEMAKER C.B., DAVID J.R. 1998: The PACAPtype I receptor agonist maxadilan from sand fly saliva protects mice against lethal endotoxemia by a mechanism partially dependent on IL-10. Eur. J. Immunol. 28: 3120 3127.

BRODSKYN C.I., GOMES R., TEIXEIRA C., SILVA C., TEIXEIRA M.J., BARRAL-NETTO M., BARRAL A., VALENZUELA J. 2005: Immunization with cDNA from Lutzomyia longipalpis salivary protein glands protects hamsters from infection by Leishmania chagasi. Third World Congress on Leishmaniosis Worldleish3, April 10
15, 2005, Palermo-Terrasini, Sicily, Italy. Abstract book p. 121.

BROWN S.J., ROSALSKY J.H. 1984: Blood leukocyte response in hosts parasitized by the hematophagous arthropods Triatoma protracta and Lutzomyia longipalpis. Am. J. Trop. Med. Hyg. 33: 499-505.

CASTRO-SOUSA F., PARANHOS-SILVA M., SHERLOCK I., PAIXAO M.S., PONTES-DE-CARVALHO L.C., DOS-SANTOS W.L.C. 2001: Dissociation between vasodilation and Leishmania infection-enhancing effects of sand fly saliva and maxadilan. Mem. Inst. Oswaldo Cruz 96: 997-999.

CAVALCANTE R.R., PEREIRA M.H., GONTIJO N.F. 2003: Anti-complement activity in the saliva of phlebotomine sand flies and other haematophagous insects. Parasitology 127: 87-93.

ČERNÁ P., MIKEŠ L., VOLF P. 2002: Salivary gland hyaluronidase in various species of phlebotomine sand flies (Diptera : Psychodidae). Insect Biochem. Mol. Biol. 32: 1691-1697.

CHARLAB R., VALENZUELA J.G., ROWTON E.D., RIBEIRO J.M.C. 1999: Toward an understanding of the biochemical and pharmacological complexity of the saliva of a hematophagous sand fly Lutzomyia longipalpis. Proc. Natl. Acad. Sci. USA 96: 15155-15160.

COSTA D.J., FAVALI C., CLARENCIO J., AFONSO L., CONCEICAO V., MIRANDA J.C., TITUS R.G., VALENZUELA J., BARRAL-NETTO M., BARRAL A., BRODSKYN C.I. 2004: Lutzomyia longipalpis salivary gland homogenate impairs cytokine production and costimulatory molecule expression on human monocytes and dendritic cells. Infect. Immun. 72: 1298-1305.

DONNELLY K.B., LIMA H.C., TITUS R.G. 1998: Histologic characterization of experimental cutaneous leishmaniasis in mice infected with Leishmania braziliensis in the presence or absence of sand fly vector salivary gland lysate. J. Parasitol. 84: 97-103.

ELNAIEM D.E.A., MENESES C., SLOTMAN M., LANZARO G.C. 2005: Genetic variation in the sand fly salivary protein, SP-15, a potential vaccine candidate against Leishmania major. Insect Mol. Biol. 14: 145-150.

GHOSH K.N., MUKHOPADHYAY A. 1998: The effect of anti-sandfly saliva antibodies on Phlebotomus argentipes and Leishmania donovani. Int. J. Parasitol. 28: 275-281.

GOMES R.B., BRODSKYN U., DE OLIVEIRA C.I., COSTA J., MIRANDA J.C., CALDAS A., VALENZUELA J.G., BARRAL-NETTO M., BARRAL A. 2002: Seroconversion against Lutzomyia longipalpis saliva concurrent with the development of anti-Leishmania chagasi delayedtype hypersensitivity. J. Infect. Dis. 186: 1530-1534.

GUILPIN V.O., SWARDSON-OLVER C., NOSBISCH L., TITUS R.G. 2002: Maxadilan, the vasodilator/immunomodulator from Lutzomyia longipalpis sand fly saliva, stimulates haematopoiesis in mice. Parasite Immunol. 24: 437-446.

HALL L.R., TITUS R.G. 1995: Sand fly vector saliva selectively modulates macrophage functions that inhibit 
killing of Leishmania major and nitric oxide production. J. Immunol. 155: 3501-3506.

KAMHAWI S., BELKAID Y., MODI G., ROWTON E., SACKS D. 2000: Protection against cutaneous leishmaniasis resulting from bites of uninfected sand flies. Science 290: 1351-1354.

KATZ O., WAITUMBI J.N., ZER R., WARBURG A. 2000: Adenosine, AMP, and protein phosphatase activity in sandfly saliva. Am. J. Trop. Med. Hyg. 62: 145-150.

KILLICK-KENDRICK R. 1990: Phlebotomine vectors of the leishmaniases: a review. Med. Vet. Entomol. 4: 1-24.

KILLICK-KENDRICK R., KILLICK-KENDRICK M., PINELLI E., DEL REAL G., MOLINA R., VITUTIA M.M., CANAVATE M.C., NIETO J. 1994: A laboratory model of canine leishmaniasis: the inoculation of dogs with Leishmania infantum promastigotes from midguts of experimentally infected phlebotomine sandflies. Parasite 1: $311-318$.

KLEIN J., HOŘEJŠÍ V. 1997: Immunology. Blackwell Science, Oxford, $722 \mathrm{pp}$.

LANZARO G.C., LOPES A.H.C.S., RIBEIRO J.M.C., SHOEMAKER C.B., WARBURG A., SOARES M., TITUS R.G. 1999: Variation in the salivary peptide, maxadilan, from species in the Lutzomyia longipalpis complex. Insect Mol. Biol. 8: 267-275.

LEHN M., WEISER W.Y., ENGELHORN S., GILLIS S., REMOLD H.G. 1989: IL-4 inhibits $\mathrm{H}_{2} \mathrm{O}_{2}$ production and antileishmanial capacity of human cultured monocytes mediated by IFN- $\gamma$. J. Immunol. 143: 3020-3024.

LIMA H.C., TITUS R.G. 1996: Effects of sand fly vector saliva on development of cutaneous lesions and the immune response to Leishmania braziliensis in BALB/c mice. Infect. Immun. 64: 5442-5445.

LOUZIR H., KILLICK-KENDRICK R., KILLICKKENDRICK M., BEN SALAH A., ZHIOUA E., CHELBI I., CHEMKI J., MOKNI M., DELLAGI K. 2005: Antibody to sand fly saliva in a Tunisian population at risk for zoonotic cutaneous leishmaniasis. Fifth International Symposium on Phlebotomine Sandflies ISOPS V, Gammarth-Tunis, Tunisia, April 17-21, 2005. Abstract OP-62. Arch. Inst. Pasteur Tunis 82: 80.

MBOW M.L., BLEYENBERG J.A., HALL L.R., TITUS R.G. 1998: Phlebotomus papatasi sand fly salivary gland lysate down-regulates a Th1, but up-regulates a Th2, response in mice infected with Leishmania major. J. Immunol. 161: 5571-5577.

MELO M.N., WILLIAMS P., TAFURI W.L. 2001: Influence of lysates of the salivary glands of Lutzomyia longipalpis on the development of a Leishmania-major-like parasite in the skin of the golden hamsters. Ann. Trop. Med. Parasitol. 95: 59-68.

MENON J.N., BRETSCHER P.A. 1996: Characterization of the immunological memory state generated in mice susceptible to Leishmania major following exposure to low doses of $L$. major and resulting in resistance to a normally pathogenic challenge. Eur. J. Immunol. 26: 243249.

MILLERON R.S., MUTEBI J.P., VALLE S., MONTOYA A., YIN H.Z., SOONG L., LANZARO G.C. 2004a: Antigenic diversity in maxadilan, a salivary protein from the sand fly vector of American visceral leishmaniasis. Am. J. Trop. Med. Hyg. 70: 286-293.

MILLERON R.S., RIBEIRO J.M.C., ELNAIME D., SOONG L., LANZARO G.C. 2004b: Negative effect of antibodies against maxadilan on the fitness of the sand fly vector of American visceral leishmaniasis. Am. J. Trop. Med. Hyg. 70: 278-285.

MONTEIRO M.C., NOGUEIRA L.G., SOUZA A.A.A., RIBEIRO J.M.C., SILVA J.S., CUNHA F.Q. 2005: Effect of salivary gland extract of Leishmania vector, Lutzomyia longipalpis, on leukocyte migration in OVA-induced immune peritonitis. Eur. J. Immunol. 35: 2424-2433.

MORRIS R.V., SHOEMAKER C.B., DAVID J.R., LANZARO G.C., TITUS R.G. 2001: Sandfly maxadilan exacerbates infection with Leishmania major and vaccinating against it protects against $L$. major infection. J. Immunol. 167: 5226-5230.

NORSWORTHY N.B., SUN J.R., ELNAIEM D., LANZARO G., SOONG L. 2004: Sand fly saliva enhances Leishmania amazonensis infection by modulation interleukin-10 production. Infect. Immun. 72: 1240-1247.

OLIVEIRA F., KAMHAWI S., SEITZ A.E., PHAM V.M., GUIGAL P.M., FISCHER L., WARD J., VALENZUELA J.G. 2006: From transcriptome to proteome: Identification of DTH inducing proteins from a Phlebotomus ariasi salivary gland cDNA library. Vaccine 24: 374-390.

PARANHOS M., DOS SANTOS W.C., SHERLOCK I., OLIVEIRA G.G.S., PONTES DE CARVALHO L.C. 1993: Development of eosinophilia in dogs intradermically inoculated with sand fly saliva and Leishmania (Leishmania) chagasi stationary phase. Mem. Inst. Oswaldo Cruz 88: 249-251.

PARANHOS-SILVA M., OLIVEIRA G.G.S., REIS E.A., DE MENEZES R.M.C., FERNANDES O., SHERLOCK I., GOMES R.B.B., PONTES DE CARVALHO L.C., DOS SANTOS W.L.C. 2003: A follow-up of Beagle dogs intradermally infected with Leishmania chagasi in the presence or absence of sand fly saliva. Vet. Parasitol. 114: 97-111.

QURESHI A.A., ASAHINA A., OHNUMA M., TAJIMA M., GRANSTEIN R.D., LERNER E.A. 1996: Immunomodulatory properties of maxadilan, the vasodilator peptide from sand fly salivary gland extracts. Am. J. Trop. Med. Hyg. 54: 665-671.

ROGERS K.A., DEKREY G.K., MBOW M.L., GILLESPIE R.D., BRODSKYN C.I., TITUS R.G. 2002a: Type 1 and type 2 responses to Leishmania major. FEMS Microbiol. Lett. 209: 1-7.

ROGERS K.A., TITUS R.G. 2003: Immunomodulatory effects of Maxadilan and Phlebotomus papatasi sand fly salivary gland lysates on human primary in vitro immune responses. Parasite Immunol. 25: 127-134.

ROGERS M.E., CHANCE M.L., BATES P.A. 2002b: The role of promastigote secretory gel in the origin and transmission of the infective stage of Leishmania mexicana by the sandfly Lutzomyia longipalpis. Parasitology 124: 495-507.

ROGERS M.E., ILG T., NIKOLAEV A.V., FERGUSON M.A.J., BATES P.A. 2004: Transmission of cutaneous leishmaniasis by sand flies is enhanced by regurgitation of fPPG. Nature 430: 463-467. 
ROHOUŠOVÁ I., OZENSOY S., OZBEL Y., VOLF P. 2005b: Detection of species-specific antibody response of humans and mice bitten by sand flies. Parasitology 130: 443-449.

ROHOUŠOVÁ I., VOLF P., LIPOLDOVÁ M. 2005a: Modulation of murine cellular immune response and cytokine production by salivary gland lysate of three sand fly species. Parasite Immunol. 27: 469-473.

ROJAS E., SCORZA J.V. 1995: Leishmania braziliensis: isolation of lesions by inoculation of hamsters with and without the addition of salivary gland lysates of Lutzomyia youngi. Rev. Saude Publica 29: 1-5.

SACKS D., KAMHAWI S. 2001: Molecular aspects of parasite-vector and vector-host interactions in leishmaniasis. Annu. Rev. Microbiol. 55: 453-483.

SÁDLOVÁ J. 1999: The life history of Leishmania (Kinetoplastida: Trypanosomatidae). Acta Soc. Zool. Bohem. 63: 331-366.

SAMUELSON J., LERNER E., TESH R., TITUS R. 1991: A mouse model of Leishmania braziliensis braziliensis infection produced by coinjection with sand fly saliva. J. Exp. Med. 173: 49-54.

SILVA F., GOMES R., PRATES D., MIRANDA J.C., ANDRADE B., BARRAL-NETTO M., BARRAL A. 2005: Inflammatory cell infiltration and high antibody production in BALB/c mice caused by natural exposure to Lutzomyia longipalpis bites. Am. J. Trop. Med. Hyg. 72: 94-98.

SOARES M.B.P., TITUS R.G., SHOEMAKER C.B., DAVID J.R., BOZZA M. 1998: The vasoactive peptide maxadilan from sand fly saliva inhibits TNF-alpha and induces IL-6 by mouse macrophages through interaction with the pituitary adenylate cyclase-activating polypeptide (PACAP) receptor. J. Immunol. 160: 1811-1816.

STIERHOF Y.D., BATES P.A., JACOBSON R.L., ROGERS M.E., SCHLEIN Y., HANDMAN E., ILG T. 1999: Filamentous proteophosphoglycan secreted by Leishmania promastigotes forms gel-like three-dimensional networks that obstruct the digestive tract of infected sandfly vectors. Eur. J. Cell Biol. 78: 675-689.

THEODOR O. 1935: A study of the reaction to Phlebotomus bites with some remarks of "harara". Trans. R. Soc. Trop. Med. Hyg. 29: 273-284.

THEODOS C.M., RIBEIRO J.M.C., TITUS R.G. 1991: Analysis of enhancing effect of sand fly saliva on Leishmania infection in mice. Infect. Immun. 59: 15921598.

THEODOS C.M., TITUS R.G. 1993: Salivary gland material from the sand fly Lutzomyia longipalpis has an inhibitory effect on macrophage function in vitro. Parasite Immunol. 15: 481-487.

THIAKAKI M., ROHOUŠOVÁ I., VOLFOVÁ V., VOLF P., CHANG K.P., SOTERIADOU K. 2005: Sand fly speciesspecificity of saliva-mediated protective immunity in Leishmania amazonensis-BALB/c mouse model. Microbes Infect. 7: 760-766.

TITUS R.G. 1998: Salivary gland lysate from the sand fly Lutzomyia longipalpis suppresses the immune response of mice to sheep red blood cells in vivo and concanavalin A in vitro. Exp. Parasitol. 89: 133-136.

TITUS R.G., RIBEIRO J.M.C. 1988: Salivary gland lysates from the sand fly Lutzomyia longipalpis enhance Leishmania infectivity. Science 239: 1306-1308.

TITUS R.G., RIBEIRO J.M.C. 1990: The role of vector saliva in transmission of arthropod-borne disease. Parasitol. Today 6: $157-160$.

TRAVI B.L., OSORIO Y., GUARIN N., CADENA H. 1998: Leishmania (Leishmania) chagasi: clinical and parasitological observations in experimentally infected Didelphis marsupialis, reservoir of New World visceral leishmaniasis. Exp. Parasitol. 88: 73-75.

VALENZUELA J.G., BELKAID Y., GARFIELD M.K., MENDEZ S., KAMHAWI S., ROWTON E.D., SACKS D.L., RIBEIRO J.M.C. 2001: Toward a defined antiLeishmania vaccine targeting vector antigens: characterization of a protective salivary protein. J. Exp. Med. 194: 331-342.

VALENZUELA J.G., GARFIELD M., ROWTON E.D., PHAM V.M. 2004: Identification of the most abundant secreted proteins from the salivary glands of the sand fly Lutzomyia longipalpis, vector of Leishmania chagasi. J. Exp. Biol. 207: 3717-3729.

VALENZUELA J.G., OLIVEIRA F., SEITZ A., PHAM V.M., KAMHAWI S., LAWYER P., ROWTON E., BRODSKYN C., BARRAL A., BARRAL-NETTO M., GOMEZ R., DE OLIVEIRA C.I. 2005: From massive cDNA sequencing to functional genomics of sand fly salivary glands. Fifth International Symposium on Phlebotomine Sandflies ISOPS V, Gammarth-Tunis, Tunisia, April 17-21, 2005. Abstract OP-46. Arch. Inst. Pasteur Tunis 82: 59.

VOLF P., ROHOUŠOVÁ I. 2001: Species-specific antigens in salivary glands of phlebotomine sandflies. Parasitology 122: 37-41.

VOLF P., TESAŘOVÁ P., NOHÝNKOVÁ E. 2000: Salivary proteins and glycoproteins in phlebotomine sandflies of various species, sex and age. Med. Vet. Entomol. 14: 251256.

WAITUMBI J., WARBURG A. 1998: Phlebotomus papatasi saliva inhibits protein phosphatase activity and nitric oxide production by murine macrophages. Infect. Immun. 66: 1534-1537.

WARBURG A., SARAIVA E., LANZARO G.C., TITUS R.G., NEVA F. 1994: Saliva of Lutzomyia longipalpis sibling species differs in its composition and capacity to enhance leishmaniasis. Philos. Trans. R. Soc. Lond. B 345: 223-230.

WARBURG A., SCHLEIN Y. 1986: The effect of postbloodmeal nutrition of Phlebotomus papatasi on the transmission of Leishmania major. Am. J. Trop. Med. Hyg. 35: 926-930.

WHO July 2005: http://www.who.int/tdr/diseases/leish/

ZER R., YAROSLAVSKI I., ROSEN L., WARBURG A. 2001: Effect of sand fly saliva on Leishmania uptake by murine macrophages. Int. J. Parasitol. 31: 810-814. 